\title{
GENETIC ANALYSIS OF DEFENSIVE BEHAVIOUR OF HONEYBEE COLONIES (APIS MELLIFERA L.) IN A FIELD TEST
}

\author{
Robin F.A. MORITZ*, Edward E. SOUTHWICK *, John B. HARBO** \\ * Department of Biological Sciences, State University of New York \\ Brockport NY 14420, U.S.A. \\ ** Bee Genetics and Physiology Laboratory \\ U.S.D.A., A.R.S., 1157 Ben Hur Rd., Baton Rouge, LA 70820, U.S.A.
}

\begin{abstract}
SUMMARY
Defensive behaviour in a population of honeybee colonies was determined in a field test. High, medium, and low defensive colonies were selected, which provided queens and drones to produce 36 test colonies. An incomplete diallel mating system allowed for estimating genetic variance components and maternal effects in a sib analysis. The estimates of the realized heritability revealed a strong asymmetry for low $\left(h_{R}{ }^{2}=0.3\right)$ and high $\left(h_{R}{ }^{2}=0.57\right)$ defensive behaviour. This asymmetry probably results from non-linear weather effects, occuring during the season-long field tests, which have a stronger effect on selection for low defensive behaviour than for high defensive behaviour.
\end{abstract}

\section{INTRODUCTION}

Since the rapid dispersion of Africanized honeybees in South America (KERR, 1967), the defensive behaviour of colonies in the genus Apis has been subject to numerous studies (STORT, 1974, 1975 a, 1975 b, 1975 c, 1976 ; FUCHS and Koeniger, 1978 ; Koeniger et al., 1979 ; Collins et al., 1982 ; Collins and Kubasek, 1982. Though the sterotype behavioural pattern of colony defense and its pheromonal control in Apis mellifera is well known (Maschwitz, 1963, 1964 ; Boch and Shearer, 1971; Blum, 1969 ; Crewe, 1976), a large quantitative variation of this behaviour has been found in field studies (Collins et al., 1984). A wide variety of possible factors which determine the intensity of this economically important character has been reported. This ranges from the effect of climatic and metereological factors (SHUA, 1952 ; WoYKE, 1973 ; Rothenbuhler, 1974 ; Collins, 1981 ; Brandburgo et al., 1982; SouthWICK and Moritz, 1986) over the effect of empty comb (Collins and 
RINDERER, 1985) to the impact of genetic variation on this behaviour (Collins, 1979 ; Collins et al., 1984).

There have been several approaches attempted in order to determine the selectability of defensive behaviour. Laboratory tests have given especially promising results, predicting a fair selectability of this character (i.e. heritability in the narrow sense $=\mathrm{h}_{\mathrm{n}}{ }^{2}$, Collins, 1979 ; Collins et al., 1984 ; Rinderer et al., 1983 ; Moritz et al., 1986). The estimates for the selectability reported in field tests, however, were smaller and showed large variances with values ranging from 0 to 0.66 (Collins et al., 1984). In most studies the estimates of $h_{n}{ }^{2}$ resulted from a sib analysis in which the sire variance component was used as the basic estimator for additive genetic variance. MoRITz (1986) suggested that this value, originally designed for the estimation of genetic variance of individual characters, may also be a useful estimator for genetic variance of group characters. Interactions among the various workers involved in defensive behaviour, however, cannot be analysed with classical sib analyses. A more powerful prediction of selectability can be made when the actual response to selection is determined. Knowing the mean phenotypic values of the parents, parent population, and offspring the realized heritability can be estimated as follows (PIRCHNER, 1979).

where :

$$
\mathrm{h}_{\mathrm{R}}{ }^{2}=\frac{\mu-\mathrm{Y}}{\mu-\mathrm{P}}
$$

$$
\begin{aligned}
& \mu=\text { population mean } \\
& \mathrm{Y}=\text { offspring mean } \\
& \mathrm{P}=\text { mean of selected parents. }
\end{aligned}
$$

In the present study we compare heritability estimates resulting from sib analysis, parent offspring regression and the realized heritability. We also determine the impact of maternal effects on defensive behaviour.

\section{MATERIALS AND METHODS}

The defensive behaviour of honeybee colonies ( $A$. mellifera L.) was tested in the field using the following target test. The lid of each hive was removed and a circle piece of filter paper $(10 \mathrm{~cm}$ diameter), soaked with $2 \mathrm{ml}$ isopentyl acetate (I.P.A., a major compound of the alarm pheromone, Boch et al., 1962) was placed in the center of the top of the colony. A suede leather target $(5 \mathrm{~cm} \times 5 \mathrm{~cm})$ was moved back and forth $1 \mathrm{~cm}$ above the hive for $15 \mathrm{sec}$. This test was repeated after two days and the average number of stings per target was used to quantify defensive behaviour.

Six breeder colonies, two with high, two with medium and two with low defensive behaviour, were selected with the above test from a population of 30 colonies, at the Bee Breeding and Stock 
Center Laboratory in Baton Rouge, LA. The selected colonies produced the queens and drones for a diallel test-cross system as shown in table 1. Semen of more than 100 drones of each breeder colony was collected. These semen samples were diluted 1 to 10 in a buffer $0.05 \mathrm{M}$ tris $\mathrm{HCl}$ buffer (pH 8.7) containing Arginine and Lysine (0.1\% each), and Glucose ( $1 \%$ ), and homogeneously mixed. The semen pools were reconcentrated by centrifugation at $1000 \mathrm{~g}$ for 5 min and immediately used for insemination of 12 queens per sire colony (for detailed insemination techniques see Moritz, 1983). This allowed for a more accurate estimate of genetic variances, since each queen in a sire group was inseminated with genetically identical semen pools. The diallel, crossed also enabled us to document the effects of disruptive and stabilizing selection.

The queens were introduced into equal size colonies (10 frames) and after 10 weeks the field tests were started. In this time the offspring of the introduced queens had replaced most workers af the original queen. The field tests described above were performed on all 36 colonies at weekly intervals over a three month time period (July to September) at the apiary of the State University of New York in Brockport NY.

TABL. 1. - Insemination pedigree of the experimental colonies

\begin{tabular}{|c|c|c|c|c|c|c|}
\hline \multirow{2}{*}{ Queen mother } & \multicolumn{6}{|c|}{ Drone mother } \\
\hline & $\mathbf{L}_{1}$ & $\mathbf{L}_{2}$ & $\mathbf{M}_{1}$ & $\mathbf{M}_{2}$ & $\mathrm{H}_{1}$ & $\mathrm{H}_{2}$ \\
\hline $\mathbf{L}_{\mathbf{1}}$ & - & $\mathbf{L}_{1} \mathbf{L}_{\mathbf{z}}$ & 一 & $\mathbf{L}_{1} \mathbf{M}_{2}$ & - & $\mathbf{L}_{\mathbf{\lambda}} \mathbf{H}_{2}$ \\
\hline $\mathrm{L}_{2}$ & $\mathbf{L}_{2} \mathbf{L}_{1}$ & - & $\mathbf{L}_{2} \mathbf{M}_{1}$ & - & $\mathbf{L}_{2} \mathrm{H}_{1}$ & - \\
\hline $\mathbf{M}_{1}$ & - & $\mathrm{M}_{1} \mathrm{~L}_{2}$ & $\ldots$ & $\mathbf{M}_{1} \mathbf{M}_{2}$ & - & $\mathrm{M}_{1} \mathrm{H}_{2}$ \\
\hline $\mathbf{M}_{2}$ & $\mathbf{M}_{2} \mathbf{L}_{1}$ & - & $\mathbf{M}_{\mathbf{2}} \mathbf{M}_{1}$ & - & $\mathrm{M}_{2} \mathrm{H}_{1}$ & - \\
\hline $\mathrm{H}_{1}$ & - & $\mathrm{H}_{1} \mathrm{~L}_{22}$ & - & $\mathbf{H}_{1} \mathbf{M}_{2}$ & 一 & $\mathbf{H}_{1} \mathbf{H}_{2}$ \\
\hline $\mathbf{H}_{2}$ & $\mathrm{H}_{2} \mathrm{~L}_{1}$ & - & $\mathbf{H}_{2} \mathbf{M}_{\mathbf{1}}$ & - & $\mathrm{H}_{2} \mathrm{H}_{1}$ & 一 \\
\hline
\end{tabular}

An incomplete diallel set was used in order to avoid inbreeding. $\mathbf{L}=$ low defensive behavior, $\mathbf{M}=$ medium defensive behavior, $\mathbf{H}=$ high defensive behavior. Two colonies in each behavioural group (subscript 1 or 2) were used to produce drones and queens for the next generation. A replicate of each cross was made, giving a total of 36 colonies involved in the experiment.

\section{RESULTS}

Figure 1 shows the distribution of the number of stings per test for each colony in the field test prior to selection (mean : $52.4 \pm 9.1$ ). The data fit a normal distribution and there is no significant deviation from normality $\left(\mathrm{r}_{\mathrm{Q}}=0.98\right.$, $\mathrm{p}<0.01$; JoHNSON and WicherN, 1980). The field test was repeated on two different days and we found a significant rank correlation of the number of stings per target between the test days (Spearman's $r_{s}=0.48, p<0.01$ ). Two colonies each were selected from the extremes and the average (dark areas in figure 1) for the production of the next generation (the most aggresive colonies could not be selected because of a brood foul infection). The actual average numbers of stings per target of the selected colonies were 77.0, 73.4 (high), 49.4, 47.4 (medium), and 36.2, 25.6 (low) respectively. 


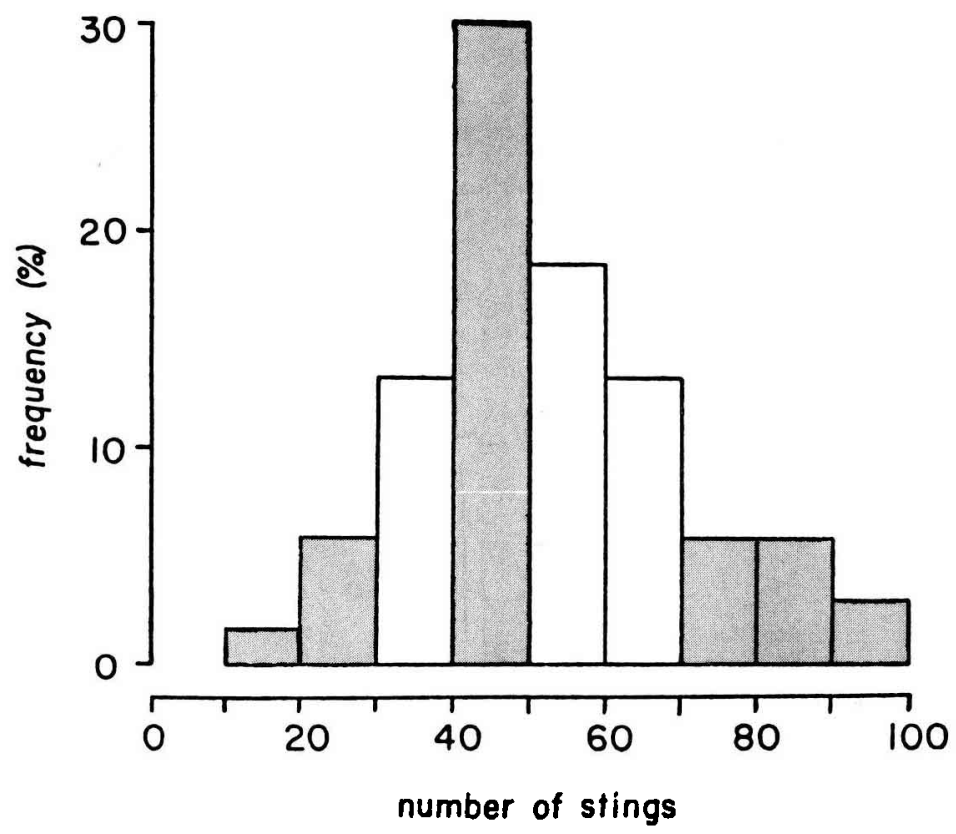

Fig. 1. - Distribution of the number of stings per test in the Baton Rouge parent population before selection (Frequency in \%)

Two colonies from each of the shaded areas were used for the production of drones and queens used for the further breeding.

TABL. 2. - Average numbers of stings of the selected parents and estimates of realized heritability in offspring on ten consecutive test days

\begin{tabular}{|c|c|c|c|c|c|c|c|c|c|c|c|c|}
\hline & \multirow{2}{*}{ Parent } & \multicolumn{11}{|c|}{ Number of stings in offspring (10 test days) } \\
\hline & & $\# 1$ & $\# 2$ & $\# 3$ & \# 4 & \# 5 & \# 6 & \# 7 & \# 8 & \# 9 & \# 10 & Mean \\
\hline Low. & 30.9 & 2.3 & 10.5 & 13.0 & 13.0 & 4.0 & 2.0 & 7.7 & 9.5 & 8.7 & 7.3 & 7.80 \\
\hline Med. & 48.4 & 3.6 & 22.6 & 16.6 & 24.0 & 16.6 & 1.0 & 13.5 & 12.3 & 8.5 & 11.5 & 13.02 \\
\hline High & 75.2 & 17.3 & 41.6 & 28.0 & 36.3 & 28.0 & 15.0 & 41.0 & 23.3 & 17.7 & 36.6 & 28.48 \\
\hline$\Delta$ low & -1.75 & -1.3 & -12.1 & -3.6 & -11.0 & -12.6 & +1.0 & -6.8 & -2.8 & +0.2 & -4.2 & -5.32 \\
\hline$\Delta$ high & 26.8 & 13.7 & 19.0 & 11.4 & 12.3 & 11.4 & 14.0 & 27.5 & 10.9 & 9.2 & 25.1 & 15.36 \\
\hline Low $h_{r}^{2}$ & & 0.07 & 0.69 & 0.21 & 0.63 & 0.72 & -0.05 & 0.39 & 0.16 & $\rightarrow 0.01$ & 0.24 & 0.30 \\
\hline High $h_{r}^{2}$ & & 0.51 & 0.71 & 0.43 & 0.46 & 0.43 & 0.52 & 1.03 & 0.37 & 0.34 & 0.94 & 0.57 \\
\hline$r_{Q}$ & & 0.88 & $0.99 *$ & 0.93 & $0.98 *$ & $0.99 *$ & 0.91 & 0.94 & 0.91 & 0.92 & 0.95 & 0.92 \\
\hline
\end{tabular}

Since parents and offspring were tested under extremely different environments, the offspring from the disruptive selection was compared to the phenotype of colonies resulting from a stabilizing selection, rather than the mean of the parent population. $\Delta$ low and $\Delta$ high is the deviation of the average number of stings from the corresponding population mean of the low and the high-line respectively. $r_{Q}$ is the correlation of the data to normality on the corresponding test days $(* \mathrm{p}<0.01)$. The realized heritabilities are given seperately for each test day. 


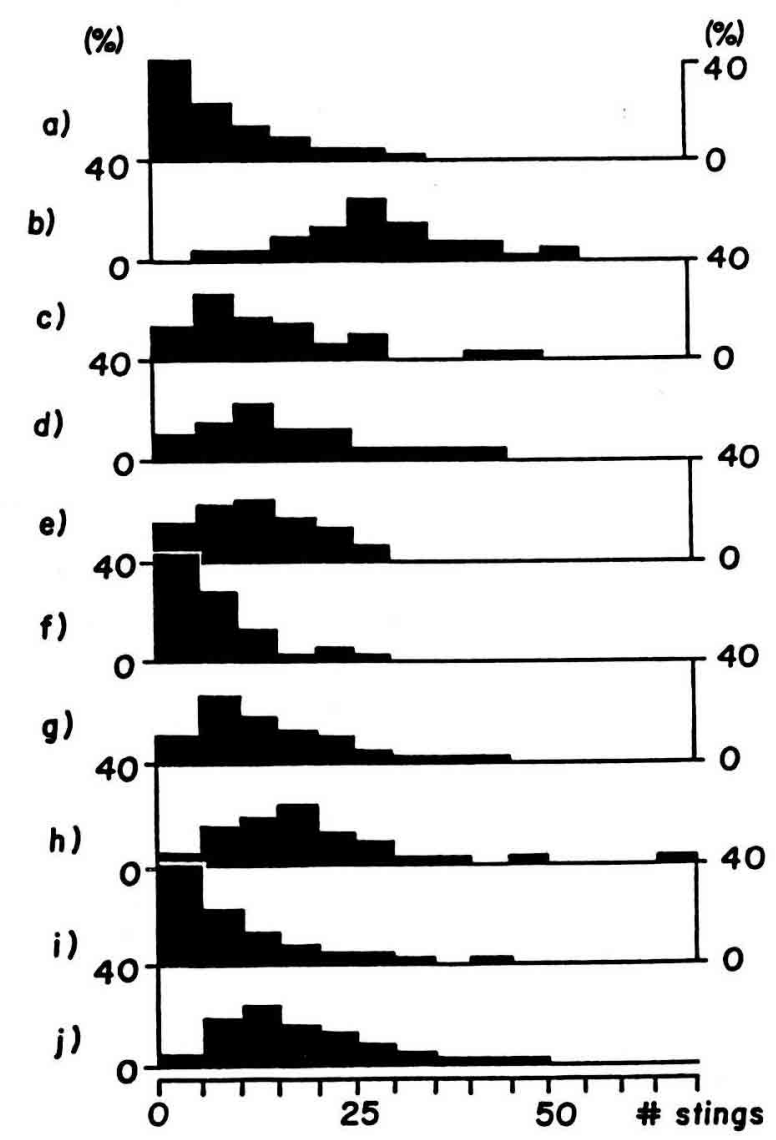

Fig. 2. - Distribution of the actual number of stings per test on ten different test days (a to j) from. July to September

The data are grouped in classes of 5 and the frequency is given ( $x$-axis). On most days there is a significant deviation from normality.

Figure 2 shows the distribution of the number of stings of the offspring colonies on ten different test days (July to August). On most days we found asymmetric poisson-type distributions. There were symmetrical distributions on a few test days which fit closely to a normal distribution. We can see from the data in table 2 that only on those days with a good fit to the normal distribution, were the estimates for the realized heritability high and fairly symmetric for high and low defensive behaviour. On other test days there was a strong asymmetry between the two estimates of the realized heritability. This resulted in a high variability for the heritability estimate of the low defensive trait. Also the distribution of the average number of stings per test throughout the season $(15.2 \pm 2.8$; 
figure 3) was asymmetric and there was no significant correlation to an expected normal distribution $\left(\mathrm{r}_{\mathrm{Q}}=0.92\right.$, n.s.).

The effect of the various environmental conditions of different test days on the number of stings per colony, as well as the colony effects, is shown by a non parametric rank analysis of variance (Freidman test, SACHS, 1975). There was a highly significant effect of both environment and colony $\left(\chi^{2}=100.47\right.$, $\chi^{2}=148.04$ ). A classical two way ANOVA (table 3), which may be affected by the non-normality of the data, shows that the effect of colony and environment is within the same range ( $27.6 \%$ and $25.0 \%$ of total variation).

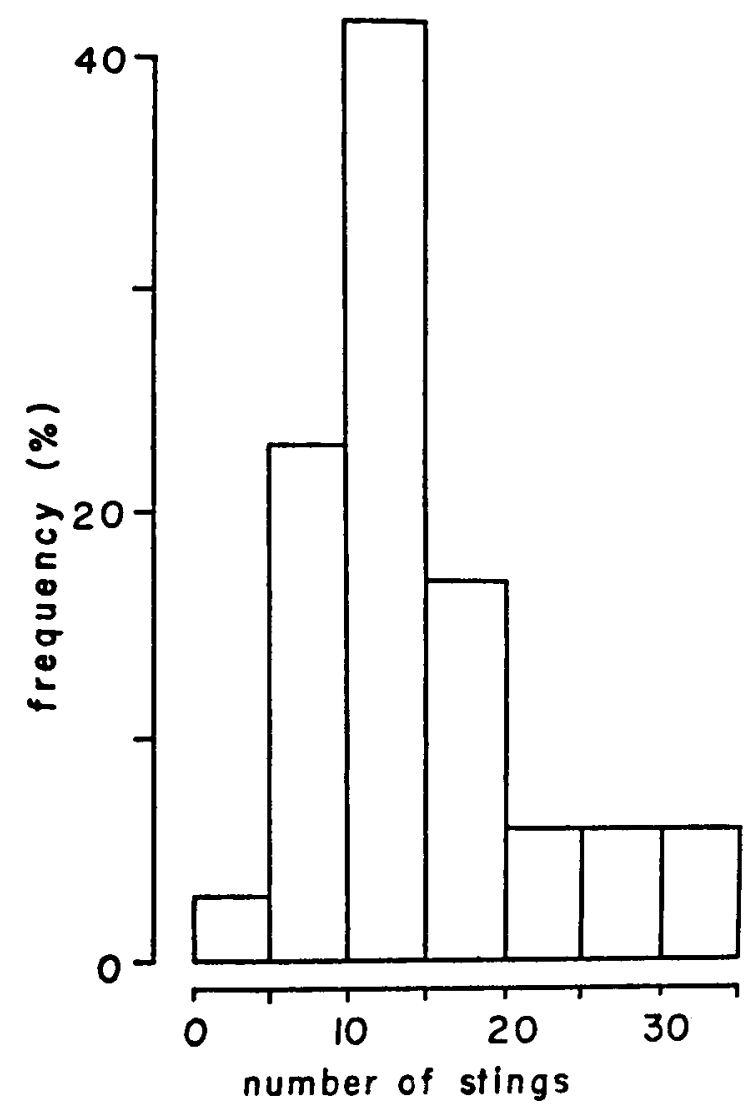

FIG. 3 - Distribution of the average number of stings per test in the offspring population in New York State after selection

The average number of stings is lower than in the parent population, most likely due to the environmental differences between Louisiana and New York (SOUTHWICK and MorITZ, 1986). 
TABL. 3. - Analysis of variance for the documentation of environment and colony effect on the number of stings

\begin{tabular}{l|c|c|c|c|c|c}
\hline $\begin{array}{c}\text { Source of } \\
\text { variance }\end{array}$ & $\begin{array}{c}\text { Degr. } \\
\text { freedom }\end{array}$ & $\begin{array}{c}\text { Sum of } \\
\text { squares }\end{array}$ & $\begin{array}{c}\text { Mean of } \\
\text { squares }\end{array}$ & $\begin{array}{c}\text { Variance } \\
\text { component }\end{array}$ & $t$ & $F$ \\
\hline Days & 9 & 13543.74 & 1504.86 & 39.71 & 0.25 & $19.98^{*}$ \\
Colonies & 35 & 18018.00 & 514.80 & 43.95 & 0.28 & $6.84^{*}$ \\
Error & 315 & 23719.50 & 75.30 & 75.30 & & \\
\hline Total & 359 & 51711.92 & 144.04 & 158.96 & & \\
\hline
\end{tabular}

The measurements on separate test days are considered individually in this analysis. $t=$ intraclass correlation, $* \mathrm{p}<0.01$.

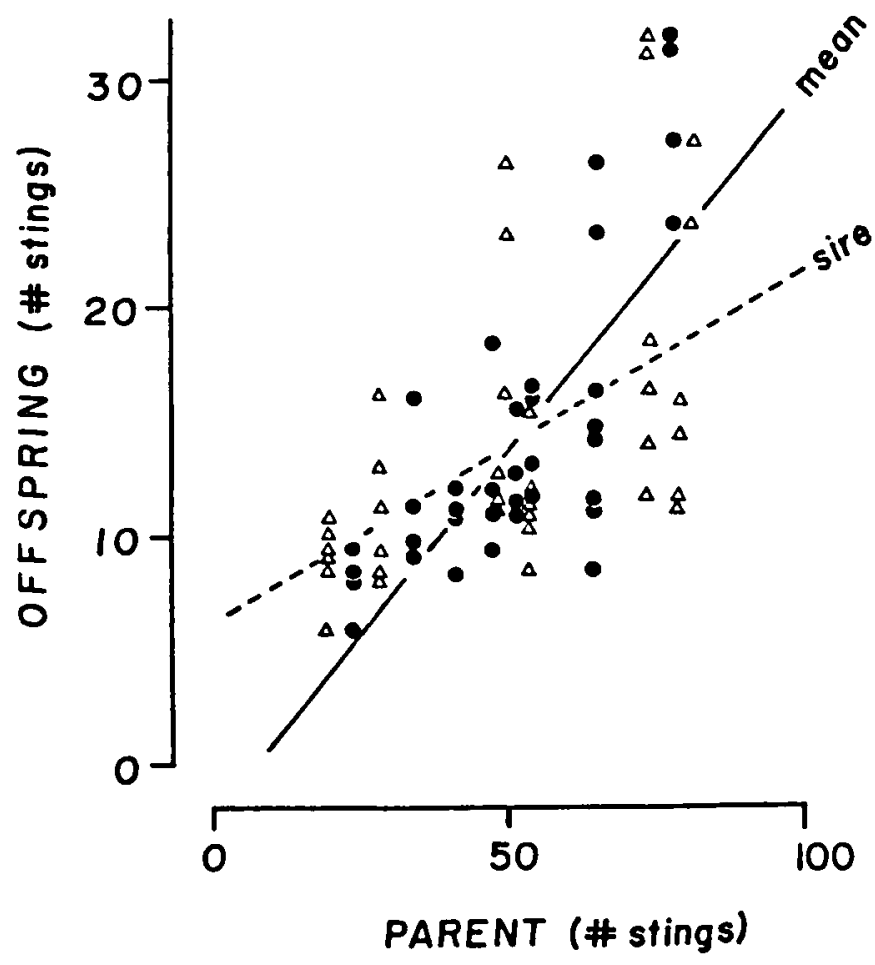

FIG. 4. - Regression of number of stings of offspring on parent mean (๑) and sire value $(\triangle)$

-... Sire regression function.

—_ Parent mean regression function. 
Figure 4 shows the regression of the number of stings of the offspring colonies on the parents mean $\left(b_{P}\right)$ and on the sire value $\left(b_{m}\right)$. Using the approach given by MORITZ (1986) for estimating genetic variances of group characters, we obtained similar estimates for $\mathrm{h}^{2}$ from both procedures $(0.38$ and 0.32 respectively). Since the environment between Louisiana and Naw York State is extremely different, this value may be not very meaningful, since usually selection would be performed in the same geographic area. When we tried to correct for the differences in environment between parent and offspring by using the data from the offspring population as a control population, the estimate of the heritability was substantially higher. Though the variance of the offspring population might have been increased by the diallel breeding scheme, the population mean should not have been affected by our selection, when we standardized the parent data to the offspring mean and variance, the corrected heritabilities were 1.5 or 1.28 respectively (table 4 ). These estimates, however, suffer from a strong standard deviation of 1.2 or 1.9 respectively and have only poor predictive power.

TABL. 4 a. - Since the actual number of males in the natural matings of the sire and dam is not known, we assumed 10 drones per mating (KOENIGER, 1986) for estimating the relationship between dams and offspring

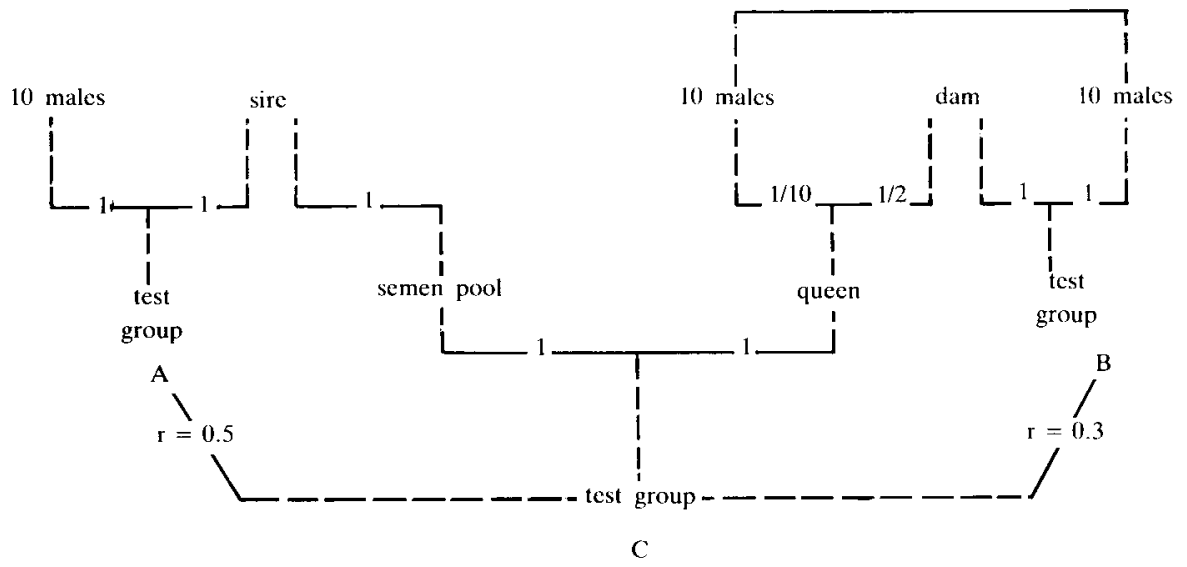

The above pedigree shows the relationships between dams, sires and offspring. Since large groups of workers were tested in our field test and not individuals, we have to consider the following probabilities for gene transmissions. All of the sire's or dam's genes are represented in test groups A or B respectively. All of the sire's genes are represented equally in the semen pool and therefore in the test group $C$. Only half of the dam's genes are represented in test group $C$. Taking into account the 10 males mating with the dam, we obtain a group relationship of $\mathrm{r}_{\mathrm{EC}}=0.3$ and $r_{A C}=0.5$. 
TABL. 4 b. - Estimate of $h^{2}$ and regression of number of stings of offspring colonies on parents mean or sire value (= number of stings of drone mother colony)

\begin{tabular}{l|c|c}
\hline \multicolumn{1}{c|}{ Coefficients } & Parent mean \pm SE & Sire value \pm SE \\
\cline { 2 - 3 } Constant & $-1.05 \pm 2.57$ & $6.14 \pm 2.33$ \\
$\mathrm{~b}$ & $0.30 \pm 0.05$ & $0.16 \pm 0.04$ \\
Relationship : & & \\
$\quad$ dam (B-C) & 0.30 & - \\
sire (A-C) & 0.50 & 0.50 \\
Heritability : & & \\
$\quad \mathrm{h}^{2}$ & $0.38 \pm 0.05$ & $0.32 \pm 0.08$ \\
$\mathrm{~h}^{2 *}$ & $1.50 \pm 0.20$ & $1.28 \pm 0.32$ \\
\hline
\end{tabular}

$\mathbf{h}^{2 *}$ is an estimate of the heritability, in which the actual parent data are standardized to the mean value of the offspring generation, in order to compensate for the different environmental conditions between Louisiana and New York.

TABL. 5. - Sib analysis for the estimation of the Sire and Dam variance components and the interactions (Sire $\times$ Dam) between both factors

\begin{tabular}{l|c|c|c|c|c|c}
\hline \hline $\begin{array}{c}\text { Source } \\
\text { of variance }\end{array}$ & $\begin{array}{c}\text { Degr. } \\
\text { freedom }\end{array}$ & $\begin{array}{c}\text { Sum of } \\
\text { Squares }\end{array}$ & $\begin{array}{c}\text { Mean of } \\
\text { squares }\end{array}$ & $\begin{array}{c}\text { Variance } \\
\text { component }\end{array}$ & t \pm SD & F \\
\cline { 1 - 6 } Sire & 5 & 685.95 & 137.19 & 20.68 & $0.41 \pm 0.11$ & $28.76^{* *}$ \\
Dam & 5 & 702.35 & 140.47 & 21.23 & $0.42 \pm 0.12$ & $29.45^{* *}$ \\
Sire $\times$ Dam & 7 & 91.75 & 13.11 & 4.17 & $0.08 \pm 0.46$ & $2.75^{*}$ \\
Error & 18 & 86.01 & 4.77 & 4.77 & & \\
Total & 35 & 1566.06 & 44.74 & 50.85 & & \\
\hline
\end{tabular}

Only the average number of stings per test per colony are used. $* * p<0.001, * p<0.05$.

The results of the sib analysis, which are independent of the environmental differences between Louisiana and New York, are shown in table 5. Genetic variances were estimated using the intraclass correlation of group characters according to the procedure suggested by MoRitz (1986). Maternal effects were estimated using the model of WiLlham (1963). Direct maternal effects and interactions between offspring and mother queen were not seperately analysed and combined in one maternal variance component, $m$. Standard arrors of the estimate for the intraclass correlation were calculated according to equation 13.2.6 of SNEDECOR and Cochran (1980). Modifying Falconer's (1980) equation for the estimation of the heritability for individuals to groups 
TABL. 6 a. - Pedigree for the estimation of relationships among offspring colonies within sires and dams
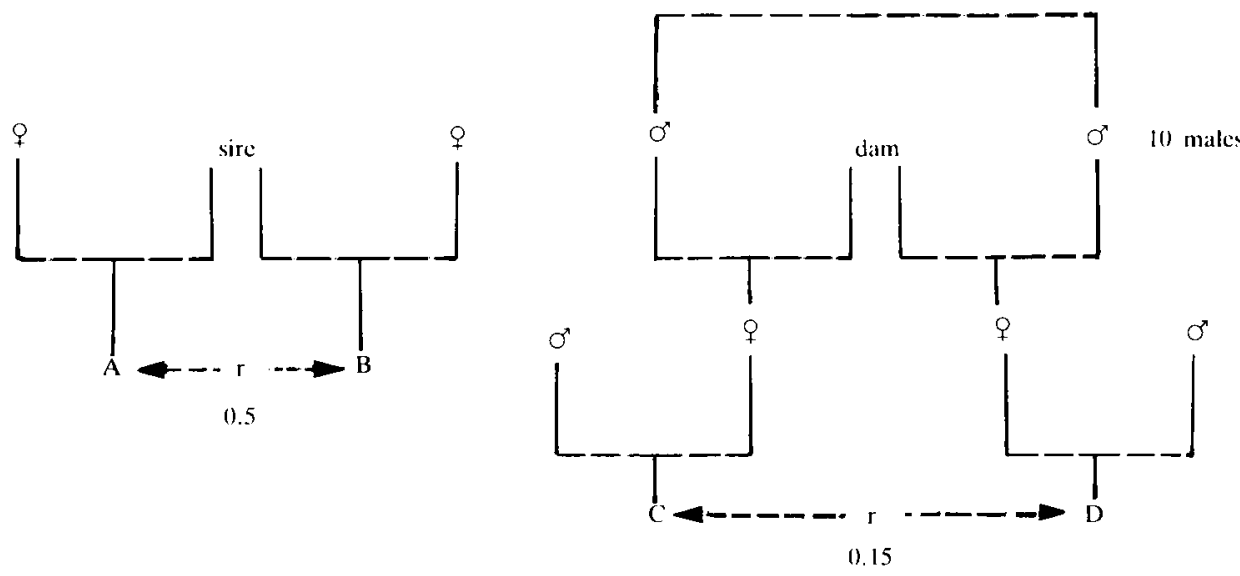

A, B and C, D represent large groups of workers tested in the field tests. The relationship between $A$ and $B$ is $1 / 2$, whereas the relationship between $C$ and $D$ is $r_{{ }^{\circ} \mathrm{D}}=9 / 10 * 1 / 8+1 / 10 * 3 / 8=0.15$.

TABL. 6b. - Estimates of additive gene effects, dominance and maternal effects on the defensive behaviour of honeybee colonies from the data in table 5

\begin{tabular}{l|c|c|c}
\hline $\begin{array}{c}\text { Variance } \\
\text { component }\end{array}$ & $\begin{array}{c}\text { Expected genetic } \\
\text { variance }\end{array}$ & $\begin{array}{c}\text { Estimate } \\
\text { of variance }\end{array}$ & $\begin{array}{c}\text { Genetic } \\
\text { parameter }\end{array}$ \\
\hline Sire & $\begin{array}{c}0.5 \sigma_{\mathrm{A}}{ }^{2} \\
\text { Dam }\end{array}$ & $\begin{array}{c}\sigma_{\mathrm{A}}{ }^{2}=41.36 \\
\sigma_{\mathrm{M}}{ }^{2}=50.08 \\
\sigma_{\mathrm{N}}{ }^{2}=11.12\end{array}$ & $\begin{array}{c}\mathrm{h}_{\mathrm{n}}{ }^{2}=0.81 \pm 0.20 \\
\mathrm{~m}=0.98 \pm 0.34 \\
\mathrm{~d}=0.22 \pm 0.62\end{array}$ \\
\hline
\end{tabular}

$S_{\mathbf{A}}{ }^{2}=$ additive genetic variance.

$\mathrm{S}_{\mathrm{M}}{ }^{2}=$ maternal variance.

$S_{1}{ }^{2}=$ dominance variance.

$\mathrm{h}_{\mathrm{n}}{ }^{2}=$ heritability in the narrow sense (selectability).

$\mathrm{m}=$ maternal effects.

d $=$ dominance effects.

(2)

$$
\mathrm{h}^{2}=\mathrm{t} / \mathrm{r}^{*}
$$

where :

$\mathrm{t}=$ intraclass correlation ;

$\mathrm{r}^{*}=$ probability for genes identical by descent in two groups of worker bees involved in the defence reaction within sires or dams respectively. 
and the model in table 6 , the estimate for the selectability from the sire variance component was $\mathrm{h}_{\mathrm{R}}{ }^{2}=0.81 \pm 0.20$ (SD) and the estimate for the maternal component from the dam variance was $m=0.98 \pm 0.34$ (table 6). Variance due to sire $\mathrm{x}$ dam interactions was estimated with $\mathrm{d}=0.22 \pm 0.62$.

\section{DISCUSSION}

The estimates of genetic variance components in the present study must be appropriately evaluated. We did not estimate classical individual heritabilities and we see problems in assigning a classical breeding value for defensive behaviour of groups to an individual queen. Nevertheless we could show in the sib analysis that colony phenotype variation can be partitioned into additive genetic, maternal, and interaction variance components. The estimates from the offspring on parent regression as well as the estimates for the realized heritability suggest reasonable chances for successful selection against defensive behaviour. However, the high variability of the realized heritability of defensive behaviour of honeybee colonies is in the same range as estimates obtained with different test procedures (CoLLINS et al., 1984). It is well documented that environmental factors, such as electric field (WARNKe, 1974), temperature (RothenbuhleR, 1974) and humidity (Collins, 1981) strongly affect defensive behaviour in the field. Eliminating the genetic variance, these factors, together with solar radiation and wind speed, can determine up to $92 \%$ of the defence reaction of a colony (Southwick and Moritz, 1986). Therefore it is not surprising to find highly variable heritabilities for this character in field tests, when there are no replicates of the tests on numerous test days under various metereological conditions. In climatic regions which have a long honeybee season, many observations on defensive behaviour will be possible, resulting in an accurate estimate of the realized heritability. In poor weather conditions, however, small heritabilities are to be expected, since the distribution of the number of stings per colony deviates substantially from normality. Under such conditions «average » colonies may produce only a small number of stings in the test and therefore cannot be distinguished from true « docile $»$ ones. This effect may explain the asymmetry between the realized heritability of the «high-line» and the «lowline». Highly defensive colonies could always be detected, regardless of the particular environmental conditions on a certain test day.

In spite of the substantial environmental variance, the estimates for the genetic variance component from the average data of a whole season are in the same range as estimates resulting from behavioural and physiological laboratory tests (Collins, 1979; RINDERER et al., 1983). The heritability estimate of defensive behaviour is well above the range of other colony characters (eg. honey production PirchNer et al., 1962; SOLler and 
BAR Cohen, 1968) if the data from «optimal» days, when the colonies show their maximal defensive behaviour are used. The high estimates of $h_{R}{ }^{2}$ in this study, however, strongly rely on the maintenance of a control population. The simple comparison of parent and offspring results in substantially smaller estimates as shown for the parent offspring regression. The high estimates for the heritability from the sib analysis may be partially due to the selection prior to the diallel mating scheme. Disruptive selection is expected to increase genetic variations which can result in overestimates of the genetic variance components.

Though maternal effects apparently have a considerable effect on the expression of the group phenotype the analysis does not allow for accurate estimates of direct maternal effects and such effects resulting from an interaction between queen and workers. Particularly for complex colony characters, such as brood production, where both queen and workers directly are involved in the expression of the phenotype, queen-worker interactions play an important role (BIENEFELD, 1986). This may be not an important factor in our present study of alarm behaviour, since exclusively workers are involved in the defense reaction, but we cannot rule out such effects definitely. Often covariances due to queen-worker interaction have negative values (BIENEFELD, 1986) which might explain our case in which the sum of additive, maternal and sire $\mathrm{x}$ dam interaction components is larger one.

For practical selection under field conditions, the technique presented seems to have sufficient accuracy as long as replicate tests are performed. The technique can be easily adapted to populations which are highly defensive, by reducing the test time or the amount of IPA used as initial stimulus. In low defensive populations the dose or the test time should be incerased until symmetric distributions are obtained. In contrast to laboratory tests, the costs of the field tests are low and more realistic for large scale selection operations in the field. Particular skills, expensive equipment, or personal experience is not necessary to perform this field test. In practical bee breeding, however, one should carefully examine the actual distribution of the population before selection. In a case of asymmetric distributions replicates of the test are crucial to get the necessary breeding information.

Received for publication in December 1985. Accepted for publication in August 1986.

\section{ACKNOWLEDGEMENT}

We are grateful to Dr. E.H. ERIckson for supplying bees and equipment necessary for this study. Financial support was given by the Alexander von Humboldt-Stiftung (R.F.A.M.) and the Research Foundation of the State University of New York (E.E.S., R.F.A.M.). 


\title{
RESUME
}

\section{ANALYSE GENETIQUE DU COMPORTEMENT DEFENSIF DE COLONIES D'ABEILLES PAR UN TEST EN CHAMP}

Le comportement défensif de colonies d'abeilles a été étudié dans un test en champ. On a enlevé le toit des ruches et introduit un morceau de papier filtre imprégné de $2 \mathrm{ml}$ d'acétate d'isopentyle (l'un des constituants principaux de la phéromone d'alarme) sur le sommet de la colonie en son centre. Une cible en velours $(0,2 \times 5 \times 5 \mathrm{~cm})$ était déplacée d'avant en arrière à $1 \mathrm{~cm}$ au-dessus de la ruche pendant $15 \mathrm{sec}$. Au bout de ce laps de temps, la colonie était refermée et le nombre d'aiguillons plantés dans la cible compté.

On a sélectionné à partir d'une population naturelle 2 colonies avec un comportement défensif faible, deux autres avec un comportement moyen et deux autres avec un comportement défensif élevé. Un système d'accouplemnet diallèle incomplet a permis de déterminer les facteurs du milieu, les facteurs dus à la colonie (tabl. 3), la variance génétique (tabl. 4, 5 et 6), ainsi que l'hérédité réalisée (tabl. 2). L'influence des effets maternels sur la variance phénotypique générale a été estimée à $21 \%$.

Cela montre que les expériences en champ pour quantifier le comportement défensif sont fortement influencées par les conditions du milieu. Les résultats obtenus s'écartent souvent fortement de la répartition symétrique, ce qui conduit à une asymétrie entre l'héritabilité réalisée pour les lignées fortement défensives et celle pour les lignées faiblement défensives. L'utilisation d'une population témoin et des répétitions fréquentes du test ont conduit dans notre étude à une augmentation décisive de l'héritabilité. Malgré ces restrictions la technique présentée semble également utilisable pour des problèmes de sélection appliquée. La durée du test et le stimulus initial (dose de phéromone) doivent bien sûr être adaptés aux conditions du milieu, de telle sorte que l'on puisse obtenir des répartitions symétriques dans la population.

\section{ZUSAMMENFASSUNG}

\author{
GENETISCHE ANALYSE DES VERTEIDIGUNGSVERHALTENS \\ VON BIENENVOLKERN (APIS MELLIFERA L.) IN EINEM FELDTEST
}

In einem Freilandtest wurde das Verteidigungsverhalten von Bienenvölkern quantifiziert. $2 \mathrm{ml}$ Isopentylacetat (Hauptkomponente des Alarmpheromons) wurden auf ein Filterpapier gegeben. Der Deckel der Beute wurde entfernt, das Filterpapier aufgelegt und eine Feindattrappe aus Verlourleder $(0,2 \times 5 \times 5 \mathrm{~cm})$ wurde im Abstand von $2 \mathrm{~cm}$ über dem Volk hin und her bewegt. Nach $15 \mathrm{sec}$. wurde das Volk wieder geschlossen und die Anzahl Stachel in der Attrappe gezählt.

In einer Population von natürlich gepaarten Königinnen wurden je zwei Völker mit starkem (high), mittlerem (medium) und schwachem (low line) Verteidigungsverhalten selektiert (Abb. 1). Mit Hilfe eines inkompletten diallelen Paarungssystems (Tab. 1) konnten Umwelt- und Volkeffekte (Tab. 3), genetische Varianzen (Tab. 4, Tab. 5 und Tab. 6) sowie die realisierte Heritabilität (Tab. 2) bestimmt werden. Der Einfluss maternaler Effekte auf die gesamte phänotypische Varianz wurde auf $21 \%$ geschätzt.

Es zeigt sich, dass Freilandverfahren zur Quantifizierung des Verteidigungsverhaltens stark von Umweltbedingungen beeinflusst werden. Oftmals weichen die beobachteten Ergebnisse stark von symmetrischen Verteilungen ab, was zu einer Asymmetrie zwischen der realisierten Heritabilität für die low- und highline führt. Die Verwendung einer Kontrollpopulation und häufige Wieder- 
holungen des Tests führen zu einer entscheidenden Erhöhung der Heritabilität in der vorliegenden Arbeit (Tab. 4). Trotz dieser Einschränkungen erscheint das vorgeschlagene Verfahren auch für angewandte Zuchtfragestellungen brauchbar. Testdauer und initialer Stimulus (Pheromongabe) müssen allerdings den entsprechenden Umweltbedingungen so angepasst werden, dass symetrische Verteilungen in der Population aufgezeigt werden können.

\section{REFERENCES}

BIENEFELD K., 1986. - Heritabilitätsschätzungen von Leistungseigenschaften bei der Honigbiene. Apidologie, 17 (4), 353-356.

Blum M.S., 1969. - Alarm pheromones. Annu. Rev. Entomol., 14, 57-80.

Boch R., Shearer D.A., 1971. - Chemical releasers of alarm behaviour in the honeybee, Apis mellifera L. J. Insect. Physiol., 17, 2277-2285.

Boch R., Shearer D.A., Stone B.C., 1962. - Identification of Iso-amyl-acetate as an active component in the sting pheromone of the honeybee. Nature, 195, 1018-1020.

Branderurgo M.M., Gonçalves L.S., Kerr W.E., 1982. - Effects of Brazilian climatic conditions upon the aggressiveness of africanized honeybees. In : Social Insects in the tropics. Ed. P. Jaisson, Presses de l'Université Paris XIII, Vol. I, pp. 256-280.

Collins A.M., 1979. - Genetics of the response of the honeybee to an alarm chemical, isopentyl acetate. J. Apic. Res., 18, 285-291.

Collins A.M., 1980. - Effect of age on the response to alarm pheromones by caged honeybees. Ann. Entomol. Soc. Amer., 73, 307-309.

Collins A.M., 1981. - Effects of temperature and humidity on honeybee response to alarm pheromones. J. Apic. Res., 20, 13-18.

Collins A.M., Kubasek K.J., 1982. - Field test of honey bee colony defensive behavior. Ann. Entomol. Soc. Am., 75, 383-387.

Collins A.M., Rinderer T.E., 1985. - Effect of empty comb on defensive behavior of honey bees. J. Chem. Ecol., 11, 333-338.

Collins A.M., Rinderer T.E., Harbo J.R., Bolton A., 1982. - Colony defense by European and Africanized honeybees. Science, 218, 72-74.

Collins A.M., Rinderer T.E., Harbo J.R., Brown M.A., 1984. - Heritabilities and correlations for several characters of the honey bee. J. Hered., 75, 135-140.

Crewe R.M., 1976. - Aggressiveness of honeybees and their pheromone production. S. Afric. J. Sci., 72, 209-212.

Dickerson G.E., 1962. - Implications of genetic-environmental interactions in animal breeding. Anim. Prod., 4, 47-55.

Falconer D.S., 1980. - Introduction to Quantitative Genetics. Longman, London, New York.

Fuchs S., Koeniger N., 1974. - Schallerzeugung im Dienst der Kolonieverteidigung bei Apis cerana. Apidologie, 5, 271-287.

Johnson R.A., Wichern D.W., 1982. - Applied Multivariate Statistical Analysis. Prentice Hall, Englewood Cliff, NJ.

KERR W.E., 1967. - The history of the introduction of African bees in Brazil. S. Afric. Bee J., 39, 3-5.

KOENIGER G., 1986. - Reproduction and mating behavior. In : Bee Breeding and Genetics. Ed. T.E. Rinderer, pp. 255-280. Academic Press, New York. 
KoENiger N., 1978. - Differences in optical releasers of attack flight between Apis mellifera carnica and Apis mellifera adansonii. Intern. Symp. Apimondia, Florianopolis, p. 56.

Koeniger N., Weiss J., Maschwitz U., 1979. - Alarm pheromones of the sting in the genus Apis. J. Insect. Physiol., 25, 467-476.

Maschwitz U., 1963. - Gefahrenalarmstoffe und Gefahrenalarmierung bei sozialen Hymenopteren. Z. vergl. Physiol., 47, 596-655.

Maschwitz U., 1964. - Alarm substances and alarm behaviour in social hymenoptera. Nature, 204, 324-327.

Moritz R.F.A., 1983. - Homogeneous mixing of honeybee semen by centrifugation. J. Apic. Res., 22, 249-255.

MORITZ R.F.A., 1986. - Estimating the genetic variance of group characters : social behaviour of honeybees (Apis mellifera L.). Theor. Appl. Genet., 72, 513-517.

Moritz R.F.A., Southwick E.E., BreH M., 1985. - A metabolic test for the quantitative analysis of alarm behavior in the honey bee (Apis mellifera L.). J. Exp. Zool., 235, 1-5.

Pirchner F., 1979. - Populationsgenetik in der Tierzucht. Verlag P. Parey, Hamburg, Berlin.

Pirchner F., Ruttner H., Ruttner F., 1962. - Erbliche Unterschiede zwischen Ertragseigenschaften von Bienen. Int. Cong. Entomol., Vienna, Vol. 2, pp 249-254

Rinderer T.E., Collins A.M., Brown M.A., 1983. - Heritabilities and correlations of the honeybee : Response to Nosema apis, longevity and alarm response to isopentyl acetate. Apidologie, 14, 79-85.

Rothenbuhler W.E., 1974. - Further analysis of committee's data on the Brazilian bee. Am. Bee J., 114, 128 .

SHUA L., 1952. - Untersuchungen über den Einfluss metereologischer Elemente auf das Verhalten der Honigbiene. Z. vergl. Physiol., 34, 258-277.

Sachs L., 1975. - Angewandte Statistik. Springer Verlag, Berlin, Heidelberg, New York.

Snedecor W.G., Cochran G.W., 1980. - Statistical Methods. Iowa, State University Press, Ames.

SOller M., Bar COHEN N.G., 1968. - Some observations on the heritability and genetic correlation between honey production and brood area in the honeybee. J. Apic. Res., 6, 37-43.

Southwick E.E., Moritz R.F.A., 1986. - Metereological effects on defensive behaviour of honey bees (Apis mellifera L.). Int. J. Biometereol., in press.

StORT A.C., 1974. - Genetic study of the agressiveness of two subspecies of Apis mellifera in Brazil. 1. Some tests to measure aggressiveness J. Apic. Res., 13, 32-38.

STORT A.C., 1975 a. - Genetic study of the agressiveness of two subspecies of Apis mellifera in Brazil. 2. Time at which the first sting reached the leather ball. J. Apic. Res., 14, 171-175.

Stort A.C., 1975 b. - Genetic study of the agressiveness of two subspecies of Apis mellifera in Brazil. 4. Number of stings in the gloves of the observer. Behav. Genet., 5, 269-274.

StORT A.C., $1975 \mathrm{c}$. - Genetic study of the agressiveness of two subspecies of Apis mellifera in Brazil. 5. Number of stings in the leather ball. J. Kans. Entomol. Soc., 48, 381-387.

Stort A.C., 1976. - Genetic study of the agressiveness of two subspecies of Apis mellifera in Brazil 3. Time Taken for the colony to become aggressive. Cienc. Cult., 28, 1182-1185.

WARNKE U., 1974. - Effects of electric field charges on honey bees. Bee World, 57, 50-56.

Willham R.L., 1963. - The covariance between relatives for characters composed of components contributed by related individuals. Biometrics, 19, 18-27.

Woyke J., 1973. - Experiences with Apis mellifera adansonii in Brazil and Poland. Apiacta, 8, 115-116. 